\title{
What Brought Them Together? Comparative Analysis of the Normalization Processes of North Korea-Japan and South Korea-Japan
}

\author{
Yaechan Lee
}

\begin{abstract}
Most scholarship on the Korean-Japanese relationship has been focused on explaining what separates the Koreans from the Japanese rather than what had brought them together. Nevertheless, this article seeks to focus its analysis on what brought the two Koreas and Japan together. This article compares the South Korea-Japan normalization negotiations with the North Korea-Japan negotiations and purports that the controversial issues that recurrently surfaced in the process of the negotiations ultimately did not serve as a big hindrance to furthering the normalization progress in the latter and concluding negotiations in the former. Moreover, it suggests two possible scenarios under which normalization between North Korea and Japan could occur and concludes that Kim Jong-un's personality will play the most critical role in determining the direction of normalization talks.
\end{abstract}

Key Words: South Korea, North Korea, Japan, normalization, historical animosity

$\mathrm{T}$ he armistice ending the hostilities of the Korean War was signed in 1953 and the Korean peninsula entered a stalemate, with each state claiming to be the sole legitimate state on the peninsula thereafter (Tucker, Roberts, and Eisenhower 2007). Joining the United Nations as a member was a solution to achieving legitimacy but unlikely as either the Soviet Union or the United States would veto the joining of either North or South Korea. Thus, the realistic option for the two new Koreas was to quickly normalize relations with surrounding countries and achieve individual recognition from the global community. Japan, of course, was on the list, at least for South Korea during the Cold War. In fact,

*Yaechan Lee (yaechanlee@gmail.com) is an M.A. candidate in international relations at Peking University. He received a B.A. from Waseda University in Economics. 
South Korea had many incentives to normalize relations with Japan. Apart from enhancing regime legitimacy, it was also expected to bring compensation from Japan for its annexation of the peninsula from 1910 to 1945. That compensation was deemed crucial for the economic development of South Korea (Seo 1999). However, normalization failed to occur for another 13 years after the signing of the armistice and only occurred, as Victor Cha has argued, due to the U.S. factor, which coerced the two parties to converge (Cha 1996). The negotiations lagged due to the many historical and territorial issues about which the two parties disagreed. Nevertheless, as it will be further discussed in the latter parts of this article, the issues were addressed when domestic and international factors compelled the two parties to converge.

The North Korean case shows a similar pattern. With the fall of the Soviet Union, North Korea had lost its biggest financial supporter, and the death in 1994 of the North's only leader, Kim Il-Sung, led North Korea into the 'March of Suffering,' where millions reportedly died of hunger. The elder Kim's son, Kim Jong-Il, who took over as supreme leader after his father's death, was therefore naturally drawn to the negotiating table with Japan (Jang 2007). Thereafter, Kim Jong-il sought to restart normalization talks with Japan multiple times and, although historical, and territorial issues were extant, the two parties came very close to reaching an actual agreement in the 2002 'Pyongyang Declaration,' with North Korea making huge concessions (Yang and Kim 2006). The unresolved issues eventually resurfaced, however, and stalled the finalization of the negotiations, but the multiple rapprochements serve as evidence to the fact that the issues themselves did not appear as crucial when bringing the two parties together.

Most scholarship, however, has been focused on explaining what separates the Koreans from the Japanese rather than what has brought them together. The prevailing view is the historical animosity approach (Cooney and Scarbrough 2008; Gries et al. 2009; Hwang 2003; Ku 2008). Scholars have purported that this animosity has existed since Japanese warlord Toyotomi Hideyoshi's invasion in the late 16th century up through the annexation of the peninsula in 1910, which resulted in Japanese attempts to assimilate Koreans to Japanese by abolishing the written language of Korea, Hangeul, and forcing Koreans to practice Shintoism (Cha 1996). Also, other historical grudges, such as forced labor, comfort women, and going even further back into history, how Japanese invaders cut off the ears and noses of Koreans during Japan's invasions of the peninsula in the 1590s. Such historical grudges have continued to the present and have attracted research on the various issues Koreans and Japanese disagree upon.

The same trend is prevalent in the Japanese academy, as well. Kei Kogo (2016) 
focuses on the fact that the post-war discourse in Japan and Korea, respectively, created the perception gap between the two. Ryuta Itagaki (2015) examined Korea-phobia in Japan and analyzes what caused such acrimony. Taku Tamaki (2004) focused on the fact that Korea's 'taken-for-grantedness' for the massive amount of aid and funding Japan provided in the postwar era caused the Japanese public sentiment to have anti-Korean tendencies. As such, most Japanese scholars focused on defining why Japan carries animosities towards Korea from a Japanese perspective. However, scholars have not sought to tackle the question of what brings these two countries together. Therefore, this article seeks to focus its analysis on what brought the two Koreas to normalizations talks with Japan.

Now, with tensions on the peninsula easing, and North Korea more willing to break its long hermitage and enter the global community, it is timely to take such an approach and inspect under what circumstances North Korea will reconciliate with its neighbors, chiefly Japan. Looking back at the former talks these two states held in the past is therefore crucial to understanding the future talks to come, and under what scenario the two countries will finally agree to formal diplomatic ties. With such developments in mind, this article seeks to make a historical comparison between the South Korea-Japan normalization talks from 1951 to 1965 and the North Korea-Japan negotiations from 1991 to 2006 through historical research based on primary documents and secondary documents to conclude that the issues that apparently hindered the progress of these negotiations ultimately were not crucial to preventing rapprochement between the parties in both negotiations and suggest two scenarios under which normalization between North Korea and Japan may occur.

\section{SOUTH KOREA'S DOMESTIC MOTIVATIONS}

South Korea's 'mendicant mentality' had been frequently discussed since the United States started giving aid worth billions of dollars after World War II. U.S. officials berated the Korea's dependency on U.S. aid, as the South Korean economy had not achieved much economic development by the 1960s. Aiding the country without seeing any tangible return for its investment for over a decade had exhausted U.S. policymakers (Hahm 1964). Constant threats were made to withdraw support from the country if South Korea was not actively working to achieve economic independence. In response to such criticisms, the U.S. government sought to decrease aid to third world countries and establish institutes to provide loans in place of aid (Song 1970). 
Major General Park Chung-hee of the South Korean Army launched a coup in 1961 and established a military junta thereafter and was immediately faced with such pending requirements from the United States. South Korea was under extreme poverty and the United States' withdrawal of aid would mean death from starvation for many. Investment and aid from other countries were necessary prerequisites for the survival of his regime. Park began to turn his eyes to other nations, and the most plausible candidate from which to receive aid and investment as an answer to U.S. pressure was Japan (Koh 2007). Since the Korean peninsula's independence from Japanese colonialism, the two Koreas had completely cut ties with Japan and, although normalization negotiations between South Korea and Japan had been under process since 1952, the two parties were not able to converge over their disagreements (Seo 1999). The biggest disagreements were on how to interpret the annexation of the Korean peninsula and how to term the aid and loans Japan was to provide if diplomatic ties were to be restored. The South Korean side wished them to be termed as compensations, while the Japanese side saw them as property claims to the damages done during the occupational period (Yang and Kim 2006). Nevertheless, despite such disagreements, an agreement meant that aid would be provided regardless, and South Korea was desperate for it.

\section{JAPAN'S DOMESTIC MOTIVATIONS}

Japan's domestic incentives for normalization were much fewer than South Korea's, thus explaining the sluggishness of normalization talks that dragged on for more than a decade. Restoring diplomatic ties would offer Japanese companies opportunities to exploit the developing South Korean market, and Japan's economy would certainly benefit (Yoon 2008). Yet, an agreement was not a matter of life or death for Japan as it was for South Korea. Moreover, both sides had been unyielding in a variety of matters regarding history, amount of aid, and others. Minimum concessions would be necessary for the talks to proceed, and such concessions would not receive a warm welcome domestically for the Japanese. Therefore, normalizing relations with South Korea brought accompanying risk with relatively few benefits (Weaver 1997).

Looking at Japan's National Assembly records in 1965 when the normalization treaty was signed tells a similar story. The assembly stressed the importance of the treaty in the practical sense, such as clarifying the boundaries of maritime territory and the recognition of the Korean diaspora in Japan. However, what 
was recurrently emphasized was achieving domestic support for the treaty that needed to be signed. In the assembly held January 15, 1965, and also in almost every assembly that followed, Japanese Prime Minister Sato Eisaku emphasized achieving domestic support for the finalization of the treaty. "I believe that the two countries should work towards achieving support for this treaty from the majority of the citizens" (Eisaku 1965).

Of course, such domestic risks existed for South Korea as well, and the series of protests that followed the signing of the treaty speak to the risks South Korean President Park endured to achieve this treaty (Donga Ilbo 1966). However, South Korea was desperate for investment and aid to meet U.S.'s demands and prepare for a potential U.S. aid withdrawal, which made such risks bearable in comparison (Delury 2015). On the other hand, while Japan also received considerable domestic benefits, such as clarification of maritime territory for Japanese fishermen and dealing with the ambiguous identities of the Korean diaspora residing in Japan, such benefits were insignificant in comparison to South Korea's (Jang 2007).

Observing the domestic motivations of the two countries explains why South Korea was willing to make concessions. However, it does not explain why Japan, considering the relatively limited nature of the domestic benefits, decided to make concessions as well despite the many disagreements the two countries had. To explain fully this final negotiation over these divergences, international factors need to be analyzed as well.

\section{INTERNATIONAL PRESSURE (U.S. FACTOR)}

Victor Cha $(1996 ; 1999)$ argued that what finally concluded the normalization talks between South Korea and Japan was the U.S. factor. Cha contends that the heightening Cold War security environment in East Asia, along with rising threats from China and entanglements in Vietnam, had compelled the United States to put further pressure to induce the reconciliation of its two allies. The United States entered a full-scale war with North Vietnam in 1964 using the Tonkin Bay incident as a pretext, where three North Vietnam torpedoes allegedly attacked a U.S. warship (Tucker, Roberts, and Eisenhower 2007). China's successful nuclear tests in October 1964 and May 1965, along with aggressive rhetoric against Taiwan, also exacerbated the United States' perception of threat. John Delury (2015), however, focused more on the personal relationship between Japanese leader Kishi Nobusuke and Park Chung-hee, and asserted 
that their intimate relationship was the core factor that helped finalize the negotiations. This article agrees with Cha's contention, and further asserts that South Korea and Japan's reconciliation serves as an example of how countries can bypass major historical or interpretational disagreements if they do not hold practical value under international pressure.

The mutual benefits of South Korea-Japan normalization have been constantly extant. Aligning with a country that shares the same ally and values was a reasonable security choice and a necessity against the growing influence of the Soviet bloc. In terms of territory, almost the entire Northeast Asia region had entered the Soviet bloc and the remaining friendly territories for South Korea and Japan in Northeast Asia were the Republic of China (Taiwan) and each other (Cha 1999). Nevertheless, these pending security concerns were not enough to reconcile the two countries without active U.S. influence. As it may be evidenced from the seven normalization negotiations that went on for 13 years, simple pressure from the United States was not enough to reconcile the two countries (Bae 1970). The historical animosity approach may be applicable to explain the sluggishness of the process at that time. However, as the United States felt urgency in promoting concerted actions against communism in Northeast Asia, the historical animosities ultimately subsided, and the normalization treaty was signed.

\section{SOUTH KOREA-JAPAN NORMALIZATION}

Historical grievances between the two countries had certainly stalled the process of normalization. Negotiations often ended in a rupture as delegates voiced different opinions on issues related to Japanese colonialism. For instance, when Japanese delegate head Kubota Kanichi stated that the " 36 years of Japanese occupation held Korea's modernization in a lot of areas as well" during the third round of negotiations in 1952, normalization talks were discontinued until 1958 when the Japanese foreign minister admitted Kubota's mistake (Gyeonghyang Newspapers 1958). Despite such stark differences in both parties' historical perceptions, the issues that separated them were suddenly patched over under domestic and international pressure, and the articles of the normalization treaty show that concessions were made from both sides.

Article 2 of the Treaty on Basic Relations Between the Republic of Korea and Japan mentions that "all treaties or agreements concluded between the Empire of Korea and the Empire of Japan on or before August 22, 1910 are already null 
and void" (see Appendix A). The initial position of the South Korean government was that the treaties or agreements were null and void from the start as they were enforced. The result, however, shows that the South Korean government conceded by including the word "already" to signify that they were legitimate before. On the other hand, in terms of economic aid, Japan conceded and mostly agreed to the initial demands of South Korea and provided a total of $\$ 800$ million of aid and loans. The aid, however, was termed "claims" and "economic cooperation" rather than "compensation" for the occupational period, which shows that the South Korean side conceded in terms of appellation (National Law Information Center 1965).

These mutual concessions, consequently, neglected to address the disagreements that were present under domestic and international pressure. When such pressures diminished, however, the ramifications of this neglect surfaced, and the two countries still have not emotionally reconciled as a result. Nevertheless, under pressure, the two countries were able to reconcile, and this shows that practical concerns prevailed over emotional concerns in the bilateral relationship between South Korea and Japan.

\section{NORTH KOREA'S DOMESTIC MOTIVATIONS}

North Korea's economic growth rate, which in the 1950s had been even more robust than that of South Korea's, has deteriorated since the end of 1970 s and has recorded minus growth rates for nine years since 1990. Food shortage problems occurred along with such economic recession, and maintaining the regime became difficult without foreign aid. By 1993, food rationing became nearly impossible in most areas except for Pyongyang, and with the fall of Soviet Union in 1991, North Korea lost its largest aid donor (Lee 2004). Moreover, after the death of Kim Il-sung, his son and new leader of the North, Kim Jong-il, needed to stabilize the economy in earnest. Similar to how South Korea looked to Japan to supplement the United States' decreasing aid, North Korea also looked to Japan to counter its domestic problems. Thus, North Korea was finally brought to the table in 1991 to proceed with normalization negotiations with Japan.

After eight rounds of talks from 1991 to 1992, the two states failed to reach an agreement and talks stalled for another eight years. When the talks reopened in 2000, North Korea's economic situation had changed little from the early $1990 \mathrm{~s}$ and normalizing the relationship with Japan was considered as way of getting 
hard currency flowing into the North (Yang and Kim 2006). In August 2010 when the tenth round of negotiations were held, North Korea even unofficially asked for economic compensation before normalizing relations, which Japan of course rejected (Yang 1996). The two states had numerous disagreements laid out, ranging from the Japanese abductee issue to history to the nuclear issue. Nevertheless, both Japan and North Korea were mostly motivated by domestic concerns, such as the abductee issue for the former and financial assistance for the latter. Without international pressure, neither Japan nor North Korea wished to make further concessions.

The Pyongyang Declaration and the following negotiations that took place in 2002, therefore, were surprising to many as Kim Jong-il openly admitted his fault in the abductee issue and promised appropriate measures to deal with this issue (Hangook Gyeongje 2002). Japanese Prime Minister Koizumi replied with concessions on historical issues, mentioning that Japan honored former Prime Minister Murayama's apologies to Koreans (Oh 2002). Suddenly, the seemingly irresolvable issues seemed to matter little for the two countries. Both Japan and North Korea had international pressure to reconcile, but Japan's domestic troubles in terms of the abductee issue eventually ruptured the negotiations again and normalization has been postponed since.

\section{JAPAN'S DOMESTIC MOTIVATIONS}

Most of Japan's motivation to normalize relations with North Korea had initially been derived from international considerations. However, as the talks were prolonged, domestic motivations also increased as more issues surfaced. The first round of talks that were held in the early 1990 s sought to address the free travel of the Japanese wives that followed their husbands to North Korea in 1959 (Yang and Kim 2006). Then, the abductee issue surfaced when the North Korean terrorist Kim Hyun-hee, who bombed a South Korean airplane in 1987, revealed that she had learned her Japanese from a Japanese teacher named Taguchi Yaeko, who had been disappeared in Japan (Donga Ilbo 1988). Faced with strong public opinion about this matter, the Japanese government sought to tackle it in the 1990s negotiations as well, but it only brought about anger and denial from the North Korean side, which eventually contributed to ending the talks for the next eight years (Yang and Kim 2006).

As the issue became more politicized, the Japanese government was pushed to tackle this issue in earnest, and thus saw normalization talks as the forum to 
discuss this matter. The Pyongyang Declaration seemed to have resolved the issue for good as the Japanese side succeeded in receiving a formal apology from Kim Jong-il, but as the body of the abductee that Kim promised to send back was found to be of another person, further discussion on the issue was stopped as Japan began foremost to emphasize the abductee issue over the normalization issue. North Korea, on the other hand, wished to focus on the normalization issue, as receiving financial aid was its primary goal (Yang and Kim 2006). North Korea and Japan's domestic motivations finally did not converge, and the negotiations ultimately failed. Looking at the South Korea-Japan normalization case, however, shows a similar situation. The two countries' motivations also did not converge, and their enthusiasms for normalization were also asymmetric, but normalization eventually occurred. What nullified such asymmetry and the multiple issues at hand was international pressure, the U.S. factor, which North Korea and Japan lacked and still lacks. Therefore, the subsequent section will discuss the international factors that brought these two states together at times but also separated them to explain why normalization consequently failed.

\section{NORTH KOREA'S INTERNATIONAL MOTIVATIONS}

The end of the Cold War had brought about significant changes to the geopolitical landscape of Northeast Asia. South Korea normalized its relations with China only a year after the Soviet Union's fall in 1992, and South and North Korea were reconciliating rapidly with the North-South Joint Declaration signed on February 19, 1992 (Maeil Gyeongje 1992). Japan sought to avoid alienation from this reconciliatory trend and took proactive action to initiate talks (Lee 2003).

Japan lifted its sanctions on North Korea, which had been imposed after the bombing of a South Korean airliner before the Seoul Olympics, and in March 1989, Japanese Prime Minister Takeshita Noboru revealed a new interpretation of the Japanese occupation on the Korean peninsula through the assembly which included "apologies and remorse on Japan's colonial rule in the Korean peninsula including North Korea" and recognized North Korea's compensational claims from the colonial period (Donga Ilbo 1989). Thereafter, delegates from the two countries met to hold three preliminary meetings and eight official meetings within the next two years (Yang and Kim 2006).

The international factors that motivated North Korea were clear. Pyongyang had witnessed the fall of East Germany and German reunification, along with the 
fall of the Soviet Union. Considering the already widened economic gap between the two Koreas, Pyongyang faced uncertainty about the regime's survival. Moreover, North Korea also was experiencing economic hardship. Normalization with Japan was necessary to break through international encirclement and overcome economic difficulties (Lee 2003).

\section{JAPAN'S INTERNATIONAL MOTIVATIONS}

Japan's motivations were more passive. Since the end of the World War II, Japan has continually pushed for separating economics from politics in its foreign policies. In fact, even during the Cold War, Japan had diplomatic ties with Russia and it continuously attempted to make ties with Vietnam, even after the Vietnam War. Japan was one of the first western countries to establish ties with Vietnam in the post-Cold War era (Hirata 1998). Even in the case of North Korea, the Japanese government had been allowing economic civilian exchanges since 1954, and the Hatoyama government engineered such exchanges with the economics-politics separation policy as its guiding principle. Therefore, Japan's approach was a continuation of such policy tendencies. Of course, issues such as the return of the no. $18 \mathrm{Mt}$. Fuji ship's crew, or the abductee issue-which had not been politicized yet-were in consideration during the normalization process (Seo 1999). Nevertheless, these concerns were rather trivial compared to Japan's motivation to separate economics from politics. Later, such motivations deteriorated as the abductee issue got more politicized and became the foremost domestic motivation for Japan to engage in talks with North Korea.

Japan's fear of encirclement in Northeast Asia can also be the reason it wanted to quickly normalize relations with North Korea. Japan had often been the odd man out whenever the Korean peninsula entered a reconciliatory phase. When, on August 31, 1998, North Korea launched a Taepodong-1 missile across Japan, the Japanese government announced its decision to stop its involvement with the Korean Peninsula Energy Development Organization (KEDO) and stop food and other humanitarian aid to North Korea. Nevertheless, such actions alarmed South Korea, which had been pursuing its Sunshine Policy, and the United States, which had wanted regional stability. The United States and South Korea were then able to persuade Japan in a united effort to encourage Japan to remain in KEDO (Koh 2007). With Japan holding strong opinions about North Korean issues, and South Korea and the United States reluctant to actively sanction North Korea as part of appeasement policies, Japan was often late to 
join the reconciliation wave. However, upon entrance, Japan moved rapidly to improve relations with North Korea.

The North Korean nuclear issue has always been the most problematic for Japan. As what most clearly differentiated Japan's normalization process with North Korea from that with South Korea was the presence of the nuclear issue, Japan had to first wait for North Korea to make conciliatory gestures to the United States, such as dismantling nuclear facilities, and then attempt normalization (Cronin 2005). As Japan's North Korean policies were often tied to the United States under the security alliance, the other issues such as disagreements over history, abductees, and other issues continued to contribute to distrust between the two countries (DiFilippo 2008).

As can be seen from the international motivations of Japan and North Korea, both countries were induced to reconcile by the changing geopolitical scene, but they were not coerced in the same way as South Korea and Japan during their normalization process. As discussed above, Japan was persuaded by South Korea and the United States to change its hardline stance against North Korea but was not urged to normalize its relations. In fact, the normalization movement with North Korea was viewed as alarming to South Korea as it potentially might have harmed the legitimacy of the South Korean government on the peninsula (Seo 1999). Also, the United States was reluctant as well to see its ally normalize relations with a communist-bloc country with which it also did not share diplomatic ties. Therefore, the absence of the U.S. factor or strong international pressure meant that compromise on disputed issues was not forthcoming, and so finalization of normalization has yet to take place.

\section{COMPARATIVE ANALYSIS OF THE NORTH KOREA-JAPAN AND SOUTH KOREA-JAPAN NORMALIZATION PROCESSES}

Apart from the nuclear and abduction issues, the disagreements that South Korea and Japan had were almost identical to those of North Korea and Japan. Nevertheless, South Korea and Japan succeeded in finding a compromise to finalize the negotiations. Of course, the abduction issue and the nuclear issue were the most crucial issues under discussion, but it must also be noted that even the other issues have not been resolved up through the 13th round of talks, which were the last round of talks that were held. In case of the sovereignty issue, North Korea did concede a certain amount by admitting that "its sovereignty only reaches to half of the peninsula" in the third round of talks in 1991 (Lee 1991). Nevertheless, further discussions on this issue stalled, as Japan 
was reluctant to change the article of the normalization treaty with South Korea that stated that the sole sovereign state on the peninsula was the Republic of Korea (see Appendix A). Even in terms of the interpretation of the occupation of the Korean peninsula, discussions on this matter were postponed as other more important issues such as the North's nuclear program or the abduction of Japanese citizens surfaced. Finally, North Korea wished to label compensation to comfort women or forced labor "compensations," while conceding that other aid could be described as "economic cooperation." Nevertheless, Japan was not willing to concede on this matter, as well (Yang and Kim 2006).

Table 1. Comparison of Disagreements in South Korea-Japan Normalization

and North Korea-Japan Normalization Negotiations

\begin{tabular}{|c|c|c|c|}
\hline South Korea & Japan & North Korea & Japan \\
\hline $\begin{array}{l}\text { - South Korea is the sole } \\
\text { sovereign state on the } \\
\text { Korean peninsula }\end{array}$ & $\begin{array}{l}\text { - South Korea's sovereignty } \\
\text { only reaches the southern } \\
\text { half of the peninsula }\end{array}$ & $\begin{array}{l}\text { - North Korea is the sole } \\
\text { sovereign state on the } \\
\text { Korean peninsula }\end{array}$ & $\begin{array}{l}\text { - South Korea's sovereignty } \\
\text { only reaches the southern } \\
\text { half of the peninsula }\end{array}$ \\
\hline $\begin{array}{l}\text { - All previous treaties } \\
\text { signed before August } \\
22,1910 \text { are 'null and } \\
\text { void' as the Japanese } \\
\text { annexation treaty was } \\
\text { forcefully signed }\end{array}$ & $\begin{array}{l}\text { - Colonial rule is legitimate } \\
\text { under a legal treaty }\end{array}$ & $\begin{array}{l}\text { - All previous treaties } \\
\text { signed before August } \\
22,1910 \text { are 'null and } \\
\text { void' as the Japanese } \\
\text { annexation treaty was } \\
\text { forcefully signed }\end{array}$ & $\begin{array}{l}\text { - Colonial rule is legitimate } \\
\text { under a legal treaty }\end{array}$ \\
\hline \multirow[t]{3}{*}{$\begin{array}{l}\text { - The aid provided by } \\
\text { Japan is to be defined } \\
\text { as a 'compensation' not } \\
\text { 'claims' }\end{array}$} & $\begin{array}{l}\text { - The aid provided } \\
\text { by Japan is to be } \\
\text { defined as 'claims' not } \\
\text { 'compensations' }\end{array}$ & $\begin{array}{l}\text { - The aid provided by } \\
\text { Japan is to be defined } \\
\text { as a 'compensation' not } \\
\text { 'claims' }\end{array}$ & $\begin{array}{l}\text { - The aid provided } \\
\text { by Japan is to be } \\
\text { defined as 'claims' not } \\
\text { 'compensations' }\end{array}$ \\
\hline & & $\begin{array}{l}\text { - The nuclear issue } \\
\text { should not be Japan's to } \\
\text { concern }\end{array}$ & $\begin{array}{l}\text { - The nuclear issue } \\
\text { should be properly } \\
\text { addressed and facilities } \\
\text { inspected by a certified } \\
\text { international institution }\end{array}$ \\
\hline & & $\begin{array}{l}\text { - The abduction issue } \\
\text { has been resolved with } \\
\text { the } 2002 \text { Pyongyang } \\
\text { Declaration }\end{array}$ & $\begin{array}{l}\text { - Further investigation } \\
\text { on the abduction issues } \\
\text { is needed }\end{array}$ \\
\hline
\end{tabular}

Source: Author

Therefore, despite the 13 rounds of talks that were held to converge the two parties' interests, they showed no progress. At times, such as during crafting of the Pyongyang Declaration, the countries made it seem like the issues were in fact insignificant. Yet, when international pressure ceased with North Korea's 
continued nuclear testing and provocations towards South Korea, the talks returned to the starting point. The graph below by the Center for Strategic and International Studies (CSIS) shows the timeline of U.S. negotiations with North Korea, and Japan's normalization attempts in the timeline shows that these attempts were in alignment with U.S. negotiations. This demonstrates that Japan acted sensitively to the United States' relationship with North Korea (Collins 2017).

Figure 1. Negotiation Frequency Between the United States and North Korea (1990-2016) and a Timeline of Japan's Normalization Negotiations with North Korea

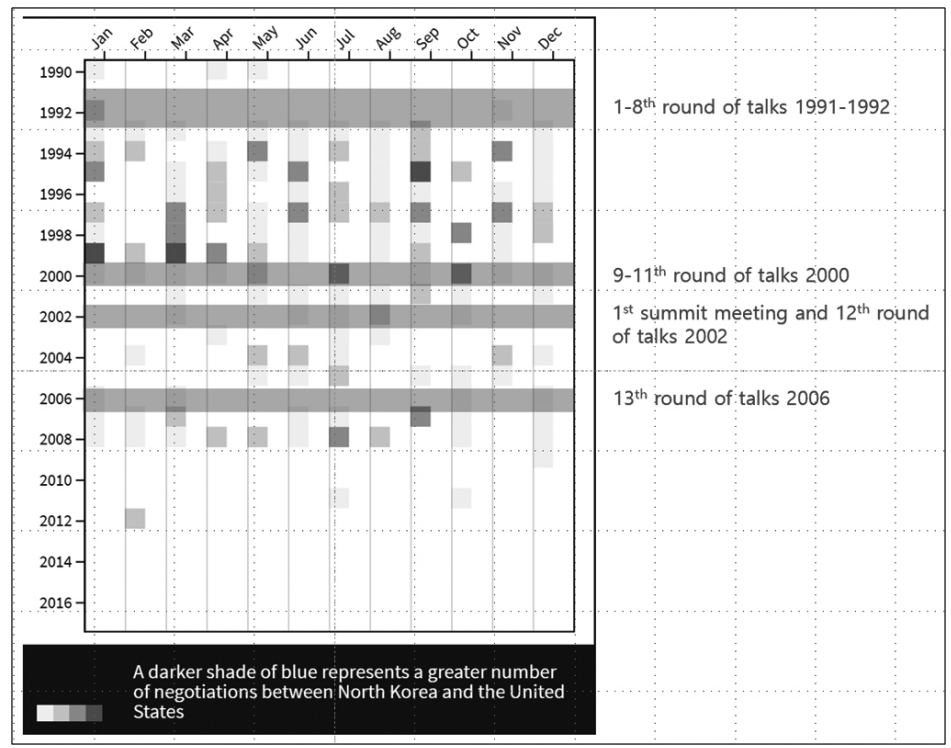

Source: Center for Strategic and International Studies (CSIS)

However, as North Korea increased provocations and the United States also ceased to negotiate further, Japan's enthusiasm for normalization also decreased. In fact, looking at the Japanese assembly records from 1991 to 2006 raises doubts about whether Japan really wished to finalize this treaty or if it was simply motivated by international pressure and domestic pressure, such as the abduction issue.

Two days before the first round of normalization talks in 1991, Japanese politicians participating in the Main Assembly gathered and voiced eagerness and enthusiasm for the talks to come: 
"Based on the joint declaration made by two Japanese parties and the Worker's Party of Korea, I strongly hope the Japanese government will move with courtesy towards the negotiations and quickly lead to normalization.”Tsuchiyi Takako, January 28, 1991 (Takako 1991).

However, in the Main Assembly following the last round of negotiations Japan held before 2000, the Cabinet Prime Minister Miyazawa Kiichi started to express a more reserved stance towards normalization talks:

"Regarding North Korea, we should dauntlessly call for complete resolution of doubts on nuclear weapon developments. Although prospects for normalization are unclear, we will make contacts with related countries and propose our position according to principles and strongly push for normalization."Miyazawa Kiichi, January 22, 1993 (Kiichi 1993).

The topic of normalization with North Korea regularly resurfaced every year in assemblies held thereafter, even when the talks were being held intermittently in line with the following rhetoric:

"Regarding normalization with North Korea, this can be the basis for stability and peace in the Korean peninsula. We will keep this strongly in mind and with courtesy, strongly push forward to reconciliation."

This rhetoric has been repeated annually, albeit with different speakers but with almost identical wording. Despite such ostensive ardor towards normalization, Japan only took tangible action when the Korean peninsula moved towards reconciliation, itself. Moreover, in later negotiations, Japan began to focus more on resolving the abduction issue at the cost of proceeding with normalization.

"Explanation on the abduction issue should be the foremost issue to be discussed. Without this, normalization negotiations should not even proceed."-Umino Tooru, November 30, 2000 (Tooru 2000).

"In terms of the abduction issue, which is of foremost importance, we should strongly ask North Korea to make further investigations on the truth, return of the survivors, and the abductors' extradition."-Koizumi Junichiro, January 25, 2006 (Junichiro 2006). 
Such sluggishness can be attributed to the fact that there was no pressing international factor to encourage normalizing the relationship with North Korea. Japan and North Korea finally failed to reach agreements even on issues in which South Korea and Japan converged because, unlike in the latter relationship, Japan and North Korea did not have the U.S. factor or any other international factors to coerce their convergence. Ostensibly, the dissonance between North Korea and Japan seems to be coming from the wider gap of understanding on a variety of issues, but looking at the South Korea and Japan and moments of rapid rapprochement between North Korea and Japan demonstrates that practical concerns have prevailed over emotional concerns. When domestic and international factors urged the two countries to converge, they converged regardless of the multiple issues at hand. However, as shown in the discussions above, the Japanese government had a strong willingness to resolve the abductee issue, placing the issue at the forefront to be resolved. Then, considering that Japan had greater willingness in the initial stages in the negotiations when the abductee issue had not yet surfaced, and even when the nuclear issue was present, the rapprochement between the two countries may occur rapidly as soon as these obstacles are removed. The sluggishness that the Japanese government showed in the latter stages of the negotiations may signify the seriousness of the abductee issue to the Japanese leadership's domestic audience. The next section, then, will discuss under which scenarios North Korea-Japan normalization may occur based on the insights gained from the comparison between the South Korea-Japan and North Korea-Japan normalization cases.

\section{SCENARIO 1}

The first scenario would show similar characteristics to that of the South KoreaJapan normalization case. If North Korea continues the recent reconciliatory attitude towards the United States, and even normalizes relations with the United States, Japan would naturally be induced to follow along, as well. In fact, the current Japanese prime minister, Shinzo Abe, has been seeking to hold a summit with the current leader of North Korea, Kim Jong-un, recently after the historic meeting between U.S. President Donald Trump and Kim (Griffith 2018). Nevertheless, international pressure alone would not suffice to ultimately draw the two countries together. South Korea and Japan's normalization was far more urgent than the normalization between North Korea and Japan. Many 
East Asian countries had joined the Soviet bloc, so forming an anti-communist alliance network was not only important to the United States, but also for South Korea and Japan to fend off the growing threats from North Korea, the PRC, and the Soviet Union (Cha 1999). Nonetheless, Japan and South Korea failed to finalize normalization for 13 years until the United States strongly urged reconciliation between the two countries. Only when international pressure became urgent did the two countries reconcile.

Considering that North Korea and Japan share the same historical grudges as did South Korea and Japan, international pressure to the level of U.S. pressure during the South Korea-Japan normalization process or even higher, keeping the presence of additional issues such as the abduction issue in mind, would be needed to nullify the disputed issues. Under what circumstances then, would such a scenario emerge? North Korea would have to first go beyond simply normalizing relations with the United States and form a strategic alliance against China. While this may sound absurd considering the decades of antagonism between the two states and the special "blood-shared alliance" between the PRC and North Korea, an examination of the Vietnam's case may make this scenario seem more plausible. ${ }^{1}$ On March 6, 2018, roughly 43 years after the Vietnam War, a U.S. warship docked in Vietnam. China's aggression in the South China Sea and the artificial islands that China has been building that are encroaching on Vietnamese waters, has brought the United States and Vietnam strategically together, enhancing the bilateral relationship to the point of allowing an ex-foe's military presence in Vietnam's territory (Rivers 2018).

Moreover, some analysts contend that North Korea's nuclear development was a method to draw the United States' attention to strike a better bargain (Daniel 2018, Graham 2018). Then, although North Korea and the United States had fought as enemies nearly seven decades ago, if strategic interests converge as with the case of Vietnam, the two countries may indeed be further drawn together. If the United States becomes a de facto ally of North Korea then Japan would face similar pressure from the United States to recognize North Korea and establish proper ties with the country. On the other hand, North Korea would also receive pressure from the United States to do likewise, which would lead to a similar scenario to that of the South Korea-Japan normalization.

However, considering the current geopolitical relationships in the region, such a radical scenario would not be probable. China lost approximately 390,000

\footnotetext{
${ }^{1}$ Coined by both scholars and journalists to describe the alliance between South Korea and the United States and the one between North Korea and China, the term "blood-shared alliance" emphasizes the intimacy and inseparability of both sets of bilateral relationships.
} 
soldiers in the Korean War, including Mao Zedong's own son, and has invested to help sustain the North Korean regime (Chu 2005). Moreover, there also are disputes regarding history and territory between North Korea and China. The relationship between North Korea and China will not likely sour in the same way they have between China and Vietnam.

\section{SCENARIO 2}

A more probable scenario would be that North Korea continues to side with its traditional allies, such as China and Russia, and opens its economy to be integrated into the world economy. For North Korea to achieve sustainable development, it would need investment and aid from as many countries as possible. South Korea, for instance, not only turned to Japan for assistance but also to Germany and other western nations to fund Park Chung-hee's economic development agenda. Park went to Germany, himself, and asked desperately for loans and aid, pleading with tears in his eyes, "half of our citizens are dying of hunger. Please lend us money and we will pay back at all costs" (Joo 2018). Park had earnestl y shown his ambition towards creating a developed, wealthy nation. Considering that under the current geopolitics of East Asia, strong pressure from the United States as in the case of the South Korea-Japan normalization process, is unlikely.

Studies on the effect of leadership personalities on a country's foreign policies have been thoroughly made with case examples such as studies of the personalities of Chinese leaders, such as Mao and Deng by Zhang (2014), and on Soviet leaders such as Khrushchev by Pyzhikov (2011). Most of the personality research, however, has focused on authoritarian states, where a single man's personality can greatly affect a country's policies due to the centralization of power. Case studies have shown that the personalities of dictators have acted as a determining factor in foreign policy decision-making, allowing room for quick and radical decisions. In an extreme authoritarian state like North Korea, the personality of the leader is even more critical. As observed in the Pyongyang Declaration, Kim Jong-il's single comment on the abduction issue seemed to have immediately solved the issue, which had been dragging on for years. Words from Kim Jong-un's conceding on the issues between Japan and North Korea may likewise bring about similar results. Whether such an attitude becomes sustainable, of course, is solely based on the solemnity of Kim to achieve development and normalization with Japan for that purpose. Yet, 
if Kim is willing to show the tears which Park showed during South Korea's developmental process, considering North Korea's authoritarian system, finding agreement on any of the present issues will not be a difficult task. This scenario would, however, almost entirely depend on the personality of Kim and, although plausible, is difficult to imagine.

\section{CONCLUSION}

Territorial, historical, and other disputes that occur between countries often impact public sentiment and, ultimately, the bilateral relationship. A comparative analysis of the normalization process between South Korea and Japan and North Korea and Japan, however, demonstrates that although such issues intially matter, under the pressure of domestic and international factors, issues eventually recede to the background as practical values overtake emotional values. In the South Korea-Japan normalization case, the U.S. factor strongly urged the two states to converge and establish diplomatic ties under the Cold War threat in the region. Their domestic pressures were asymmetric, with South Korea being more desperate than Japan, but the U.S. factor eventually worked as the most crucial factor, drawing out concessions from both parties. In the North Korea-Japan normalization case, there were apparent moments where the two parties seemed to converge on the disputed issues, making prior disagreements look insignificant. However, when international pressure ceased with North Korea's continued nuclear provocations, the issues resurfaced, and the negotiations went back to the starting point. Yet in both cases, the issues themselves were not critical when practical issues deserved more of the spotlight, and both normalization processes proceeded when doing so was more practical.

It is difficult to predict when North Korea will eventually normalize relations with Japan. The first scenario suggested above is highly improbable considering their historical geopolitical relationship in the region. Nevertheless, Kim Jongun's personality, as suggested in the second scenario, may indeed make a difference, as his father, Kim Jong-il, had in the Pyongyang Declaration. Current disputes on present issues would ultimately not matter if Kim Jong-un would decide to nullify such concerns, and then normalization may indeed be finalized. 


\section{REFERENCES}

Bae, Jaesik. 1970. "Study on the Treaty on Basic Relations between the R.O.K. and Japan [韓日基本條約硎究].” Journal of Interntional LaW 15(1), 239-265 (in Japanese).

Cha, Victor D. 1996. "Bridging the Gap: The Strategic Context of the 1965 Korea-Japan Normalization Treaty.” Korean Studies 20, 123-160. 1999. Alignment Despite Antagonism: The United States-Korea-Japan Security Triangle. Stanford, CA: Stanford University Press.

$\mathrm{Chu}$, Yun. 2005. Complete Declassficiation of the Inside Story of the Korean War [朝鲜战争内幕全公开]. Beijing: Shishi Publications [时事出版社]. (in Chinese)

Collins, Lisa. 2017. "25 Years of Negotiations and Provocations: North Korea and the United States." Center for Strategic and International Studies (CSIS).

Cooney, Kevin J., and Alex Scarbrough. 2008. "Japan and South Korea: Can These Two Nations Work Together?" Asian Affairs 35(3),173-192.

Cronin, Richard P. 2005. "The North Korean Nuclear Threat and the U.S.Japan Security Alliance: Perceived Interests, Approaches, and Prospects." The Fletcher Forum of World Affairs 29(1), 51.

Daniel, Zoe. 2018. "North Korea Leader Kim Jong-un is Capturing the World's Attention, So What is He Up To?" ABC News. Accessed at http://www. abc.net.au/news/2018-05-10/what-is-kim-jong-un-up-to/9746032 (December 16, 2018).

Delury, John. 2015. "The Kishi Effect: A Political Genealogy of Japan-ROK Relations." Asian Perspective 39(3), 441-460.

DiFilippo, Anthony. 2008. "Nuclear Deterrence and Animosity in Japan-North Korean Relations: Steps to Coexistence." Pacific Focus 2(1), 137-174.

Donga Ilbo. 1966. "Watch out for terror on journalists. South Korea-Japan nomarlization demonstrating, attention on stopping school." Donga Ilbo, 8. Accessed at http://newslibrary.naver.com/viewer/index.nhn?arti cleId $=1966102000209201014 \&$ editNo $=2 \&$ printCount $=1 \&$ publishDa te $=1966-10-20 \&$ officeId $=00020 \&$ pageNo $=1 \&$ print $\mathrm{No}=13848 \&$ publish Type $=00020 \#$ (December 16, 2018).

. 1988. "The Japanese woman who has taught Kim Hyunhee Japanese has been abducted as well. Korean intelligence agency report." Donga Ilbo. Accessed at http://newslibrary.naver.com/viewer/index.nhn?art icleId $=1988020800209201006 \&$ editNo $=2 \&$ printCount $=1 \&$ publishDa te $=1988-02-08 \&$ officeId $=00020 \&$ pageNo $=1 \&$ print $\mathrm{No}=20415 \&$ publish Type $=00020$ (December 16, 2018). 
. 1989. "Japan, recognizes North Korea's compensation claims." Donga Ilbo. Accessed at http://newslibrary.naver.com/viewer/index.nhn?art icleId $=1989031800209202013 \&$ editNo $=2 \&$ printCount $=1 \&$ publishDa te $=1989-03-18 \&$ officeId $=00020 \&$ pageNo $=2 \&$ print $\mathrm{No}=20758 \&$ publish Type $=00020$ (December 16, 2018).

Eisaku, Sato. 1965. Prime Minister Sato Eisaku's Speech on Geopolitical Policy [佐藤内閣総理大臣の施政方針に関する演説], edited by National Assembly[国会]. Tokyo, Japan: 国会議事録.

Graham, Euan. 2018. "Trump, Kim and the North Korean Nuclear Missile Melodrama." Lowy Institute. Accessed at https://www.lowyinstitute. org/publications/trump-kim-and-north-korean-nuclear-missilemelodrama (December 16, 2018).

Gries, Peter Hays, Qingmin Zhang, Yasuki Masui, and Yong Wook Lee. 2009. "Historical Beliefs and the Perception of Threat in Northeast Asia: Colonialism, the Tributary System, and China-Japan-Korea Relations in the Twenty-first Century." International Relations of the Asia-Pacific $9(2), 245-265$.

Griffith, James. 2018. "Japan Seeking Own North Korea Summit as Abe Risks Being Left Out." CNN News. Accessed at https://edition.cnn. com/2018/03/29/asia/japan-north-korea-summit-intl/index.html (December 16, 2018).

Gyeonghyang Newspapers. 1958. "Kubota Kanichi's mention was a mistkae. Japanese foreign minister's witness at the assembly." Gyeonghyang Newspapers, 4. Accessed at http://newslibrary.naver.com/viewer/ index.nhn?articleId $=1958062900329201021 \&$ editNo=2\&printCount $=1$ \&publishDate $=1958-06-29 \&$ officeId $=00032 \&$ pageNo $=1 \&$ printNo $=401$ 9\&publishType $=00020$ (December 16, 2018).

Hahm, Pyongchoon. 1964. "Korea's 'Mendicant Mentality?” Foreign Affairs.

Hangook Gyeongje. 2002. "North Korea-Japan summit. (Japanese abduction) Kim Jong-il says sorry and promises to prevent recurrence." Hangook Gyeongje. Accessed at http://news.naver.com/main/read. nhn ? mode $=$ LSD\&mid $=$ sec\&sid $1=100 \&$ oid $=015 \&$ aid $=0000549891$ (December 16, 2018).

Hirata, Keiko. 1998. "Japan as a Reactive State?: Analyzing Japan's Relations with the Socialist Republic of Vietnam.” Japanese Studies 18(2).

Hwang, Jihwan. 2003. "Rethinking the East Asian Balance of Power: Historical Antagonism, Internal Balancing, and the Korean-Japanese Security Relationship.” World Affairs 166(2), 95-108.

Itagaki, Ryuta. 2015. "The Anatomy of Korea-phobia in Japan." Japanese 
Studies 35(1), 49-66.

Jang, Sangdong. 2007. “Analysis on the N.K. and Japan Diplomatic Tie Using the Logic of Two-Level Games.” Masters, International Relations, Gyeongsang University (in Korean).

Joo, Seongha. 2018. “Joo Seongskha reporter's between Pyongyang and Seoul. Kim Jong-un, now show your sincerity.” Donga Ilbo. Accessed at http://news.donga.com/3/all/20180613/90550899/1 (December 16, 2018).

Junichiro, Koizumi. 2006. 本議会演説. edited by National Assembly [国会]. Tokyo, Japan: 国会議事録.

Kiichi, Miyazawa. 1993. 本議会演説. edited by National Assembly [国会]. Tokyo, Japan: 国会議事録.

Koga, Kei. 2016. “The Yasukuni Question: Histories, Logics, and Japan-South Korea Relations.” The Pacific Review 29(3), 331-359.

Koh, Byungchul. 2007. Between Discord and Cooperation: Japan and the Two Koreas. Seoul: Yonsei University Press.

$\mathrm{Ku}$, Yangmo. 2008. "International Reconciliation in the Postwar Era, 19452005: A Comparative Study of Japan-ROK and Franco-German Relations." Asian Perspective 32(3), 5-37.

Lee, Jooik. 1991. "North Korea Reveals a Tempered View on 'One Korea'." Hangyeorae. Accessed at http://newslibrary.naver.com/viewer/index. nhn?articleId=1991052300289101008\&editNo=4\&printCount $=1 \& p u b l$ ishDate $=1991-05-23 \&$ office $\mathrm{Id}=00028 \&$ pageNo $=1 \&$ printNo=932\&publi shType $=$ ooo10 (December 16, 2018).

Lee, Seokgi. 2004. "North Korea's Economic Crisis in the 1990 s and the Change of Enterprise Structures." Research on Economic Comparison 11(1), 139-188.

Lee, Won-Deog. 2003. "Northern Policy and Japan: North Korea-Japan Normalization Negotiations and Japanese Policy Towards North Korea." Global Economic Review 32(4), 67-94.

Maeil Gyeongje. 1992. "South-North joint declaration on denuclearization." Maeil Gyeongje. Accessed at http://newslibrary.naver.com/viewer/ index.nhn?articleId=1992010300099202009\&editNo=1\&printCount= $1 \&$ publishDate $=1992-01-03 \&$ office $\mathrm{Id}=00009 \&$ pageNo $=2 \&$ printNo $=79$ 95\&publishType=00020 (December 16, 2018).

National Law Information Center. 1965. Treaty on Basic Relations Between the Republic of Korea and Japan.

Oh, Hwaseok. 2002. "North Korea and Japan agree to start negotiations on normalization again.” Maeil Gyeongje. Accessed at http://news.naver.com/main/read. 
nhn?mode=LSD\&mid=sec\&sid1 $=$ 100\&oid $=009 \&$ aid $=0000243830$ (December $16,2018)$.

Pyzhikov, Aleksandr V. 2011. "The Cult of Personality During the Khrushchev Thaw." Russian Studies in History 50(3), 11-27.

Rivers, Matt. 2018. "US Aircraft Carrier in Vietnam for Historic Visit Aimed at Beijing." CNN News. Accessed at https://edition.cnn. com/2018/o3/o3/asia/vietnam-us-uss-vinson-intl/index.html (December 16, 2018).

Seo, Dongman. 1999. "The relationship between the South Korea-Japan's basic treaty and the North Korea-Japan's normalization negotiations." Asia Research 65-90.

Song, Geonyoung. 1970. The transition of United States' aid policy and economic aid towards South Korea. Korean Industrial Bank.

Takako, Tsuchiyi. 1991. 本議会演説. edited by National Assembly [国会]. Tokyo, Japan: 国会議事録.

Tamaki, Taku. 2004. "Taking the 'Taken-for-Grantedness' Seriously: Problematizing Japan's Perception of Japan-South Korea Relations.” International Relations of the Asia-Pacific 4(1), 147-169.

Tooru, Umino. 2000. 本議会演説. edited by National Assembly [国会]. Tokyo, Japan: 国会議事録.

Tucker, Spencer C., Priscilla Mary Roberts, and John S. D. Eisenhower. 2007. The Encyclopedia of the Cold War: A Political, Social, and Military History. Oxford, UK: Oxford University Press.

Weaver, Mark D. 1997. "American Mediation and the Japan-South Korea Normalization Treaty.” M.A., Political Science, International Law and Relations, University of New Brunswick.

Yang, Giwoong. 1996. “Japan's two level negotiation strategy: North KoreaJapan negotiations.” Journal on Reunification Research 5(1).

Yang, Giwoong, and Jundong Kim. 2006. "Some conditions of the Breakdown and resumption of the normalization negotiation between north Korea and Japan(1990-2006)." Journal on Japanese Research 23(23), 113161.

Yoon, Tae-Ryong. 2008. "Learning to Cooperate Not to Cooperate: Bargaining for the 1965 Korea-Japan Normalization." Asian Perspective 32(2), 59-91.

Zhang, Qingmin. 2014. "Towards an Integrated Theory of Chinese Foreign Policy: Bringing Leadership Personality Back In.” The Journal of Contemporary China 23(89), 902-922. 


\section{APPENDIX 1. Treaty on Basic Relations between the Republic of Korea and Japan}

Article 1 Diplomatic and consular relations shall be established between the High Contracting Parties. The High Contracting Parties shall exchange diplomatic envoys with the Ambassadorial rank without delay. The High Contracting Parties will also establish consulates at locations to be agreed upon by the two Government.

Article 2 It is confirmed that all treaties or agreements concluded between the Empire of Korea and the Empire of Japan on or before August 22, 1910 are already null and void.

Article 3 It is confirmed that the Government of the Republic of Korea is the only lawful Government in Korea as specified in the Resolution 195( III) of the United Nations General Assembly.

Article 4 (a) The High Contracting Parties will be guided by the principles of the Charter of the United Nations in their mutual relations.

(b) The High Contracting Parties will cooperate in conformity with the principles of the Charter of the United nations in promoting their mutual welfare and common interests.

Article 5 The High Contracting Parties will enter into negotiations at the earliest practicable date for the conclusion of treaties or agreements to place their trading, maritime and other commercial relations on a stable and friendly basis.

Article 6 The High Contracting Parties will enter into negotiations at the earliest practicable date for the conclusion of an agreement relating to civil air transport.

Article 7 The present Treaty shall be ratified. The instruments of ratification shall be exchanged at Seoul as soon as possible. The present Treaty shall enter into force as from the date on which the instruments of ratification are exchanged. 